CUADERNOS DE ESTUDIOS GALLEGOS, LIX Núm. 125 (enero-diciembre 2012), págs. 245-258

ISSN: 0210-847 X

DOI: $10.3989 /$ ceg.2012.125.10

\title{
SEARCHING FOR THE PARENTS AND SIBLINGS OF BENITA DE LEMA: SURNAME USAGE IN GALICIA BEFORE 1790
}

George R. Ryskamp, JD, AG

Brigham Young University 


\title{
SEARCHING FOR THE PARENTS AND SIBLINGS OF BENITA DE LEMA:
}

\author{
SURNAME USAGE IN GALICIA BEFORE 1790
}

\begin{abstract}
This genealogical reconstitution of the families of Benita de Lema eighteenth century woman from $\mathrm{Cee}$, La Coruña explores the use of surnames during this period in Galicia. Documentation drawn from parish, notary and court records shows her as mother and daughter interacting with family and society and demonstrates the flexibility in the selection of surnames throughout much of that century in Galicia. In Galicia men and women during the time before 1790 could select surnames from their fathers or mothers, from their extended pedigree, or even from their spouse's family, and often did so.
\end{abstract}

KEY WORDS: Surnames, Cee, Blanco de Lema, Genealogy

\section{BUSCANDO A LOS PADRES Y HERMANOS DE BENITA DE LEMA: EL USO DE APELLIDOS EN GALICIA ANTES DE 1790}

\begin{abstract}
RESUMEN
La reconstrucción genealógica de las líneas de Benita de Lema, mujer del siglo XVIII y natural de Cee (La Coruña), indaga acerca del uso de apellidos durante esta época en Galicia. Documentos sacados de registros parroquiales, de protocolos y de la audiencia real muestran, además de su filiación, su relación con la sociedad, y evidencia, al propio tiempo, la flexibilidad en la selección de apellidos durante la mayor parte de aquel siglo. Los hombres y las mujeres que vivieron durante el período anterior a 1790 podían escoger entre los apellidos de sus padres o sus madres, de sus linajes extendidos, o incluso entre los apellidos de las familias de sus cónyuges.
\end{abstract}

PALABRAS Clave: apellidos, Cee, Blanco de Lema, Genealogía

\section{BUSCANDO OS PAIS E IRMÁNS DE BENITA DE LEMA: O USO DE APELIDOS EN GALICIA ANTES DE 1790}

\section{RESUMO}

A reconstrución xenealóxica das liñas de Benita de Lema, muller do século XVIII e natural de Cee (A Coruña), indaga acerca do uso de apelidos durante esta época en Galicia. Documentos tirados de rexistros parroquiais, de protocolos e da audiencia real mostran, ademais da súa filiación, a súa relación coa sociedade, e evidencia, ao propio tempo, a flexibilidade na selección de apelidos durante a maior parte daquel século. Os homes e as mulleres que viviron durante o período anterior a 1790 podían escoller entre os apelidos dos seus pais ou das súas nais, das súas liñaxes estendidas, ou mesmo entre os apelidos das familias dos seus cónxuxes.

Palabras Clave: apelidos, Cee, Branco de Lema, Xenealoxía 
Recibido/Received: 31/05/2012

Aceptado/Accepted: 14/08/2012

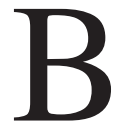

artolomé Blanco de Lema came to the United States following the harrowing experience of seeing his father washed overboard during a North Atlantic storm off the Galician coast ${ }^{1}$. In New York City Bartolomé converted a fortune, allegedly made in the slave trade, into a million dollar real estate empire ${ }^{2}$. His sudden death in 1873 and the subsequent probate of that estate brought his nephews José and Manuel Lopez Blanco to the United States ${ }^{3}$.

The place of origin of the Blanco family in Spain was easily found, as the probate of Bartolomé's estate contained the Spanish will of Josefa Blanco y Vilela, mother of Jose and Manuel, stating she was from the town of Cee, La Coruña, Spain ${ }^{4}$. The author's own experience while standing in front of the doorway to the small parish church in Cee quickly confirmed Bartolomé's connection with that small town. The inscription on the door lintel reads, "Esta puerta se hizo en 1874 por donación de Bartolomé Blanco y Vilela, el millonario, natural de Cee y vecino de Nueva York en

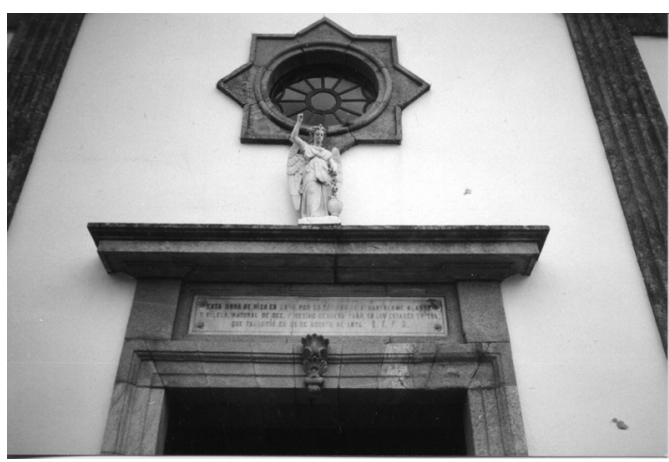

\footnotetext{
${ }^{1}$ Parish of Santa Maria, Cee, La Coruña, Spain, DEATHS, Book 3, page 59 (1816).

2 R.G. Dun \& Co. Credit Report Volumes, vol. 345, Baker Library Historical Collections, New York, Harvard Business School University, page 519.

${ }^{3}$ NEW YORK COUNTY WILLS, Book 198, page 279 (FHL Film \# 0862958), Will of Bartolomé Blanco dated 16 Aug. 1845, probated in New York 1874, appears written in Spanish.

${ }^{4}$ NEW YORK COUNTY WILLS, Book 258, Page 130, 1877 (FHL mircofilm no. 876066), will of Josefa Blanco Vilela, written in Spanish and dated 2 June 1875. The original was prepared by Francisco Ramos Vázquez, Notario del Colegio de la Ciudad de La Coruña and is found in his volume 2, pages 1009 y 1010 .
} 
los Estados Unidos, quien falleció en 18 de agosto de 1873." The record of his baptism in that parish identifies his paternal grandparents as Benita de Lema and her husband, Ambrosio Blanco de Lema5.

From that point, research in Spain presented a series of challenges relating to the patterns of surname usage employed in Bartolomé's native Galicia. The search for the siblings and parents of his paternal grandmother, Benita de Lema, offers a case study in the system of transmitting to a child several family surnames, and the use by the child of two or more of those during various periods of his or her lifetime. This system of surname usage was common in eighteenth century Galicia; is very common even into the twentieth century in Portugal (a cultural and linguistic offspring of Galicia $)^{6}$; and is found in the early seventeenth century and before throughout Spain and her colonies ${ }^{7}$.

\section{Marriage And children of Benita de Lema}

Drafted in Cee in 1788, the will of Ambrosio Blanco and Benita de Lema names their five then-living children: Tomás, Bartolomé, Domingo, Juan and Maria Jazinta. Ambrosio requests a burial in the parish church in Cee with his deceased son Pedro Blanco (a former Catholic priest), while Benita requests her burial in the tomb that she has endowed there ${ }^{8}$. Each of the six children men-

\footnotetext{
5 Parish of Santa Maria, Cee, La Coruña, Spain, BAPTISMS, Book 3, page 96v, Baptism of Bartolomé Blanco de Lema, Each of the baptismal entries for the eight siblings between 1795 and 1816 , found on pages $80 \mathrm{v}, 86 \mathrm{v}, 110 \mathrm{v}, 123 \mathrm{v}, 136 \mathrm{v}, 151 \mathrm{v}, 185 \mathrm{v}$ and 206 , likewise, identifies their paternal grandparents as Benita de Lema and her husband Ambrosio Blanco de Lema.

6 The official website of the Portuguese Ministry of Justice states: Os apelidos são escolhidos de entre os que pertençam a ambos, ou a só um dos pais, ou cujo uso qualquer um deles tenha direito, por exemplo, apelido do avô que não conste do nome do pai. Neste caso deverá ser feita prova, nomeadamente através de apresentação da certidão de nascimento do avô que prove o direito ao uso do apelido, perante o conservador que esteja a lavrar o assento de nascimento. IRN, I.P. - Instituto dos Registos e do Notariado [online] at <http://www.dgrn.mj.pt/civil/faq_civ4.asp > [Consulted: 02/03/2008].

7 George R Ryskamp, "La transmisión de apellidos en España y las Colonias Americanas (15001900)", in Eduardo Pardo Guevara (ed.), España y América, un escenario común, Santiago de Compostela, Consejo Superior de Investigaciones Científicas; Xunta de Galicia, 2005, pages 341364.

8 ARCHIVO HISTÓRICO DE LA UNIVERSIDAD DE SANTIAGO DE COMPOSTELA (AHUSC) Protocolos, José Antonio de Pazos, 1788/72 (Will of Ambrosio Blanco and Benita de Lema, Cee, 22 Dec. 1788). In addition to provisions in this will already discussed above, Benita de Lema directs that the Minerva anual she shares with her sister Theresa, which was founded by Maria de Lema, shall cease when she and her sister are dead and the monies shall be used for masses for the founders. This was the first reference found about Theresa. The partition of property by heirs of Don Ambrosio Blanco and Benita de Lema, prepared in Cee in 1800 before the same notary confirms this information. Bartholomé, Thomas and Domingo Antonio Blanco de Lema as
} 
tioned, as well as two more, Francisco and Fernando (who are presumed dead without issue prior to 1788), appear in the baptismal registers of Cee from 1744 to $1759^{9}$. These baptismal entries provide the first evidence of multiple surname use by the same individual. While Ambrosio appears in one of these with the surname of do Campo, in two with Blanco do Campo and in the others with Blanco, Benita carries the de Lema surname in each of these baptismal entries except one, where she appears as Varela de Lema. In all cases they are identified as being natives of Cee and often as from the hamlet of Son, extramuros (outside of the walls) of Cee.

An exhaustive search of the parish registers revealed only one marriage record in Cee that could be for this couple: in 1743 Ambrosio Blanco de Lema, son of Marcos do Campo ${ }^{10}$, married Benita Varela Freyre de Andrade, daughter of Juan Varela Figueroa and Ana Maria Freyre de Andrade, all from the place called Son in the parish of Cee ${ }^{11}$. The Varela surname correlates with the baptismal entry for one of her children in which Benita appears with the surname Varela de Lema, and the parentage of Ambrosio was confirmed by his appearance in their 1752 will $^{12}$, as well as numerous parish entries and a marriage dispensation petition $^{13}$.

well Jacinta de Lema wife of Juan Rodriguez Trigo and Juan Antonio Blanco (deceased) as children of Ambrosio and Benita (sons and daughters of deceased son Juan Antonio Blanco de Lema) agree how to divide the property they have inherited from their parents. Juan Antonio's widow represents, as guardian, their minor children, Juan, Domingo Antonio, Fernando and Andrea and their married daughter Maria Antonia, wife of Don Geronimo Caamaño. AHUSC, Protocolos, José Antonio de Pazos, 1788/72.

${ }^{9}$ Parish of Santa Maria, Cee, La Coruña, Spain, BAPTISMS pages 19, 59, 76v, 95v, 105, 116, 129, and 138v (1744 and 1759); none of which identify grandparents.

10 See also AHUSC, Protocolos, Bartolomé Lopez Vaamonde 1752 (14 Jun), will of Marcos do Campo, in which Ambrosio is mentioned. Also in the records of Agustin Gonzalez de Lema, notary in Cee 1716-1739, there are four appearances in 1729 of Marcos do Campo as buying property and being present to vote in the town council meeting. The 1727 list of citizens gathered in council identifies Marcos do Campo as a pescador (fisherman), which is the profession of most residents. There are also several cobblers, a locksmith, three weavers and a baker. AHUSC Protocolos Agustin Gonzalez de Lema, 1729/2, 9 and 31; and 1727/1.

${ }^{11}$ Parish of Santa Maria, Cee, La Coruña, Spain, MARRIAGES, Book 2, page 223 (1743).

12 AHUSC, Protocolos, Bartolomé Lopez Vaamonde 1752 (14 Jun), will of parents of Ambrosio Blanco de Campo, in which he is mentioned.

${ }^{13}$ In a marriage dispensation applied for in 1830 by Fernando Bernardez and Joséfa Blanco from Cee the groom goes back two generations on his genealogy, to Maria Freire and Andres Rodriguez; and the bride three generations back to Ambrosio Blanco and Benita de Lema Freire de Andrade (RIN 36), identifying Maria Freire and Ambrosio Blanco do Campo as brother and sister, children of Marcos do Campo. ARCHIVO HISTORICO DIOCESANO, SANTIAGO DE COMPOSTELA (AHDSC) Provisorato, Apostolica, B-17/1830. 
BeginNing the SEARChing For the parents and siblings of Benita VAREla DE LEMA

A careful search of all marriages in Cee back to 1695 revealed no marriage for a couple by the names Juan Varela Figueroa and Ana Maria Freyre de Andrade. Similarly, a search of all baptisms from 1710 to1729 revealed no children for that couple. The latter search was made more complicated as the earliest parish register had fallen apart and been rebound out of order. So as to be certain that all pages for those years had been covered, and to know if any pages were missing, each and every page in Book One of baptisms, marriages and deaths was reviewed and a date description of each page (starting date on the front and ending date on the back) was written down. In that process, a page at the back of the book dated December 1723 to July 1724 appeared that listed a child named Eugenia Andrea, born to Juan de Lema and Ana Maria de Lema from the place called Son.

Recognizing Benita's use of the de Lema surname, and adding to that the fact that Son contains only a few houses, the concurrence of the given names Juan and Ana Maria indicated that this could be the parents of Benita. No other children appeared for a couple with these surnames. There was, however, an Andrea Benita born to Juan de Mourelle and Ana Maria de Lema, likewise from Son, in 1721. If this were Benita de Lema, taking her mother's surname as was very common during this period ${ }^{14}$, she would have been twenty two when she married. A thorough search of the period 1710 to 1729 for any children of a Juan and Ana Maria from Son without reference to surname revealed one more child for Juan de Mourelle and Ana Maria de Lema in 1718. In the death records an entry appears in 1739 for Josepha de Lema, daughter of Juan Varela and Ana Maria de Lema, who is listed as single with no indication as to age and therefore, likely a young woman. Her birth date was approximated based on that fact and from the dates of hers siblings' births. As set forth in Figure 1, these four make a small, but perfectly-timed family of children.

\footnotetext{
${ }^{14}$ See George R. RYSKAmP, The Female Surname System in Galicia and Extremadura in the XVII Century, Riverside (California), Hispanic Family History Research, 1987. The content of this pamphlet was originally delivered at a session of the International Congress of Genealogical and Heraldic Sciences in Lisbon, Portugal in 1986.
} 


\begin{tabular}{|l|l|l|l|}
\hline Names at Baptism & Birth Dates & Marriage Data & Death Dates $^{15}$ \\
\hline Juan Antonio & 28 Dec. $1718^{16}$ & & Before 1753 \\
\hline Josepha de Lema & About $1720 ?$ & & 30 Mar. $1739^{17}$ \\
\hline Andrea Benita & 23 Mar.1721 & $\begin{array}{l}\text { 23 Aug. } 1717^{19} \\
\text { to Ambrosio Blanco }\end{array}$ & 19 Apr. 1800 \\
\hline Eugenia Andrea & 7 Apr. $1724^{20}$ & & Before 1753 \\
\hline Teresa Varela & About $1726 ?$ & $\begin{array}{l}\text { Before } 1751 \\
\text { to Francisco Ponte }\end{array}$ & After 1788 \\
\hline
\end{tabular}

Figure 1

The Family of Juan and Ana Maria. Married in Cee in August 1717

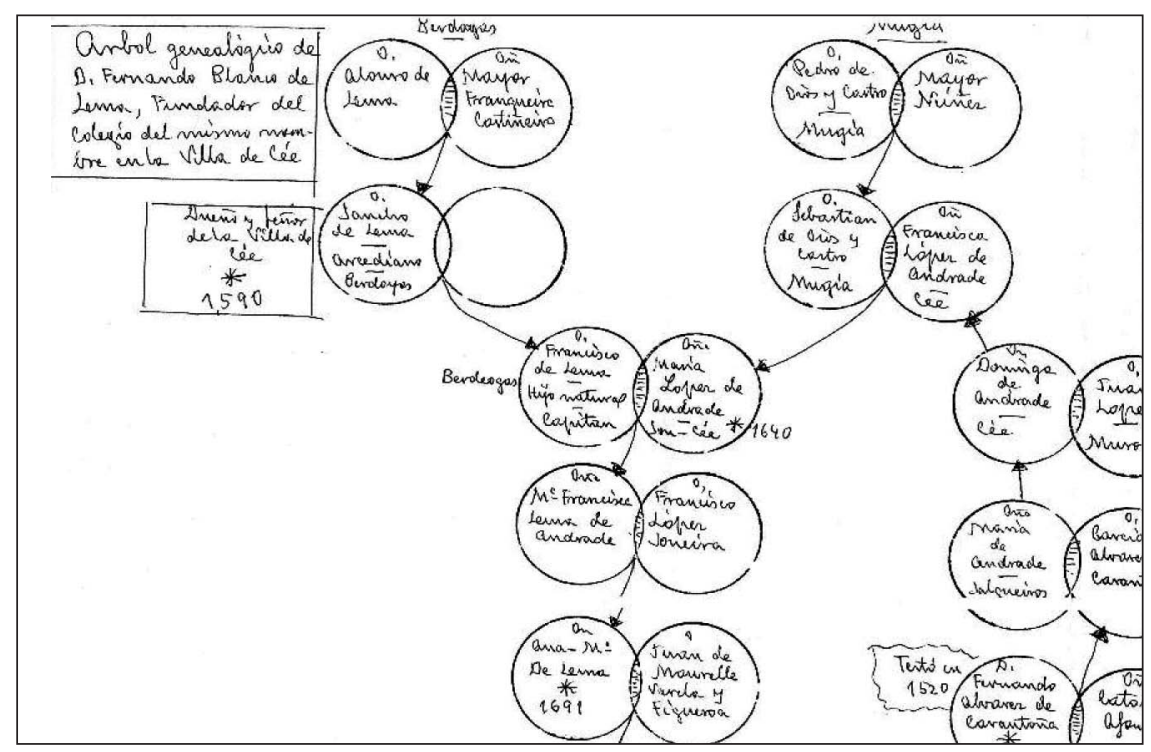

Figure 2

Portion of the Fernando Blanco de Lema Pedigree

\footnotetext{
15 Approximated death dates are based on appearance or non-appearance in the wills of Ana Maria de Lema and her daughter Benita de Lema (1788). See note 6, and accompanying text, supra, and notes 27 and 28, and accompanying text, infra.

16 Parish of Santa Maria, Cee, La Coruña, Spain, BAPTISMS, Book 1, page 160

17 Parish of Santa Maria, Cee, La Coruña, Spain, DEATHS, Book 2, page 306

18 Parish of Santa Maria, Cee, La Coruña, Spain, BAPTISMS, Book 1

19 See note 11 and accompanying text, supra.

${ }^{20}$ Parish of Santa Maria, Cee, La Coruña, Spain, BAPTISMS, Book 1 page 166v
} 
Teresa Varela, the fifth child listed in Figure 1, first appeared as the mother in a 1751 baptismal parish entry which was copied because Ambrosio Blanco and Benita de Lema were the godparents ${ }^{21}$. Later she was identified as the child of Juan Varela and Ana Maria de Lema in Ana Maria's will drafted in 1753, and as a sister of Benita de Lema in Benita's will drafted in $1788^{22}$. In all three cases she is identified as the wife of Francisco de Ponte. As there has been no opportunity to return to Cee to again review the post-1740 baptisms since completing the research in the earlier years, more detailed information about the marriage and subsequent life of Teresa Varela could almost certainly be found. The failure to find a baptism for Teresa, as well as for her sister Josepha, is most likely explained by the torn and disordered condition of the parish records before 1740 .

In a recheck of the marriages in Cee for the twenty years before 1718, only one appears for a couple with the names of Juan and Ana Maria. In August 1717 Juan de Mourelle, son of Domingo Mourelle and Margarita de Varela, married Ana Maria de Lema, daughter of Francisco Lopez and Maria de Lema. ${ }^{23}$ The groom's mother's surname adds credence to the identification of Juan Varela Figueroa with Juan de Mourelle, as does the pattern of births of his children, the marriage the year before the birth of the earliest known child, and the absence of any other possibilities in the records.

Toward the end of the research time in the parish of Cee, the priest volunteered that he had in his desk a pedigree for Fernando Blanco de Lema, founder of a local school, whom the priest thought was a cousin to Bartolomé de Lema. A portion of the pedigree is reproduced in Figure 2. The retired priest, who had prepared and left the pedigree in the parish office, also reached this same conclusion as to the parentage of Benita de Lema, and adds further credence by showing the de Andrade surname a generation earlier on the female line of Ana Maria $^{24}$.

\footnotetext{
${ }^{21}$ Parish of Santa Maria, Cee, La Coruña, Spain, BAPTISMS, Book 2 page 104.

${ }^{22}$ See notes 27 and 28 and accompanying text, infra.

${ }^{23}$ Parish of Santa Maria, Cee, La Coruña, Spain, MARRIAGES, Book 2, page 179 (1717).

${ }^{24}$ The author has a copy of this pedigree chart labeled "Arbol genealogico de D. Fernando Blanco de Lema, Fundador del colegio del mismo nombre in la Villa de Cee." which traces the de Andrade female line back to Maria de Andrade whose father Fernando de Carantona wrote a will in the year 1520. No compiler is listed on the sheet, but the parish priest verbally stated that it was researched and prepared by Don Manuel, the parish priest in the nearby town of Conciero, who in 1997 was over 90 , retired and blind.
} 
NOTARIAL RECORDS RESEARCH IN THE HISTORICAL ARCHIVES OF THE University of Santiago de Compostela (Ahusc)

During three different trips to Spain, several days were spent searching for wills or other notarial documents to further verify this emerging picture of Juan de Mourelle Varela and Ana Maria de Lema Andrade. Relevant materials concerning the family of Benita de Lema were found in the protocolos (bound notarial volumes) of three notaries of Cee: José Antonio Pazos, notary in Cee 17851812 (discussed above ${ }^{25}$ ); Agustín González de Lema, notary de Cee 1716-1739; Bartolomé Lopez Vamonde, notary in Cee 1736-1759²6.

Testament of Ana Maria de Lema, widow of Juan Varela, 7 August $1753^{27}$. This document confirms the link with daughter Benita de Lema and sonin-law Ambrosio do Campo. None of the other three children found in the parish records are mentioned, but it again mentions a daughter Teresa de Lema, stating she is married to Francisco de Ponte ${ }^{28}$.

In the protocolos of Agustin Gonzalez de Lema, notary in Cee from 1716 to1739, several records of value were found:

Will of Francisco Lopez Soneyra 16 Nov $1720^{29}$. The testator states, as a resident of the place of Son, within the parish and outside the walls of Cee being sick in bed in the house of my dwelling with an illness but of sound mind... I wish to be buried in the parish church of our Lady of Junquera in the tomb in which my father Juan Lopez Soneyra is buried which I own. I give to Ana Maria, Maria Josépha and Euxenia de Lema my daughters for all of their good assistance that they have given me in my illness and beyond the legitimate share that they would have as a result of my death I give them twelve bushels of wheat in perpetuity which none of my other children can touch. Executors: Juan Varela, my son-in-law and Da. Maria

\footnotetext{
25 See note 8 supra.

26 Other records of this notary relevant to Ambrosio do Campo are discussed above at notes 10 and 12 .

27 AHUSC, Protocolos, Bartolomé Lopez Vamonde, 1753/97.

28 In the will that Ambrosio and Benita made 1788, Benita de Lema directs that the Minerva anual she shares in with her sister Theresa, which was founded by Maria de Lema, shall cease when she and her sister are dead and the monies shall be used for masses for the founders. This was the first reference found about Theresa

29 AHUSC, Protocolos, Agustin Gonzalez de Lema, 1720/38.
} 
de Lema, my wife. Heirs: Ma. Antonia, wife of Dn. Pedro Bermudez Pereyra, resident of the parish of Sta. Maria de Brandiänas; Francisca Susana, wife of Manuel Antonio de Navas, residents of Corcubión; Ana Maria, Ma. Josépha and, Euxenia de Lema de Andrade "my legitimate children."

Will of Maria de Lema y Andrade, widow of Francisco Lopez Soneyra, $29 \mathrm{Feb} 1728^{30}$. The testatrix, as a resident of the place of Son, within the parish and outside the walls of Cee finding myself sick in bed in the house of my dwelling... I wish to be buried in the parish church in one of the tombs of the main chapel. I agree verbally to pay a debt owed to my son-in.law, Dn Pedro Bermudez Pereyra. I give to Jazinta de Lema, my grandaughter, daughter of Dn Pedro Bermudez Pereyra and my daughter Ma. Antonia his wife... Also I give to Euxenia de Lema my daughter an interest in a vinculo y Mayorasgo in the place of Paro in San Mamed, that I have from my grandparents, Sebastian de Dios and Francisca de Andrade, that was among several foundations that they made, in accordance with a testament that was prepared before Cristobal de Pasos. Executors: Juan Varela resident in Cee and Don Manuel de Navas Espinosa, resident of Corcubión, my sons-in-law . Heirs: Maria Antonia wife of Dn Pedro Pereyra resident of the parish of Sta. Maria de Brandiänas; Francisca, wife of Don Manuel de Navas, residents of Corcubión; Ana Maria, wife of Juan Varela; Josépha and Euxenia de Lema de Andrade, my legitimate children whom I had with Francisco Lopez

Sale to Anttonio Lado made by Juan Varela de Lema and his wife, 7 Mar $1728^{31}$. In the place of Son in the parish and beyond the walls of Cee... being present Juan Varela de Lema and Ana Maria de Lema y Andrade his wife, laborers and residents of the abovementioned place and parish, they sell property received from Maria de Lema y Andrade, mother of Ana Maria de Lema y Andrade and widow of Francisco Lopez Soneyra, resident of this place.

Settlement of a lawsuit, Sep $1720^{32}$. The suit arose between the Archdeacon of Trastamara and the residents of the place called Son outside the

\footnotetext{
${ }^{30}$ AHUSC, Protocolos, Agustin Gonzalez de Lema, 1138/1728/11.

31 AHUSC, Protocolos, Agustin Gonzalez de Lema, 1138/1728/15.

32 AHUSC, Protocolos, Agustin Gonzalez de Lema, 1721/19
} 
walls (extramuros) of Cee, but within its jurisdiction. The lawsuit was designed to quiet title in the lands that made up Son. Disputes had arisen in the fact that Sancho de Lema (paternal great grandfather to Benita de Lema according to the pedigree compiled by the old priest), a previous Archdeacon, had in 1644 and 1652 transferred interests in the land in Son that overlapped, had a potential to expire and/or were in excess of the total, thus creating competing interests in the recipients and the possibilities of reversions to the Archdeacon. Over 25 different parties are named, and for most a clear connection is given to the person who in 1644 or 1652 received the interest. Francisco Lopez Soneyra and his wife Doña Maria de Lema (Benita de Lema's maternal grandparents) are named as the first parties. Maria is identified as a daughter of Francisco de Lema and Maria de Andrade whose share she is receiving. Mention is made of Domingo de Mourelle as a party, but no clear statement appeared as to from whom he had received his interest.

Also, in 1727 there is one record, in 1730 two records, and another in 1737 mentioning Domingo de Mourelle, one of which identifies him as the son of Alverte de Mourelle ${ }^{33}$, all of which involve land transactions that take place only after the settlement payments on the Son lawsuit. This is assumed to be the same person as the father of Juan de Mourelle Varela, although the stated places of residence as the place called Firxe in Santa Eulalia de Memonte, or Santa Leocadia, contradict the statement made in the 1717 marriage that the groom's father, Domingo de Mourelle, is from Santa Cecilia de Roma. In all of these documents Domingo Mourelle is named as a laborer, so this can not be the Domingo Antonio de Mourelle who appears as a priest in Cee in the 1750s (and may be Juan's brother or cousin). There is also, however, a 1717 sale of property to Juan de Mourelle which says he is from Firxe ${ }^{34}$. What is most interesting in all of this is that the only appearance of the name Juan de Mourelle is in the 1717 purchase of land, the same year as his marriage. After that time, only Juan de Varela appears and the Varela surname does not appear before the 1718 birth of his first child.

\section{Research in the Archive of the Kingdom of Galicia}

Mention made in several notarial records of a lawsuit involving the estate of the maternal grandmother and great grandparents of Ana Maria de Lema led us to consult the Archivo del Reino de Galicia (ARG) in La Coruña, Spain. In addition to the types of records found in all Spanish provincial historical archives,

\footnotetext{
33 AHUSC, Protocolos Agustin Gonzalez de Lema, 1727/58, 1730/54 and 57, and 1737/1.

${ }^{34}$ AHUSC, Protocolos, Agustin Gonzalez de Lema, 1717/11.
} 
this repository houses the records of the Audiencia court, an appellate court as well as the court of first resort for many cases originally filed in the Galicia region.

Searching in the court case indexes on card files in the ARG we found a law suit filed by Francisco Lopez Soneira involving a dispute over a garden plot that led to criminal charges ${ }^{35}$. In that lawsuit, Francisco Lopez Soneira, as husband of Maria de Lema y Andrade and D ${ }^{\mathrm{a}}$ Maria Josepha, D ${ }^{\mathrm{a}}$ Euxenia and D ${ }^{\mathrm{a}}$ Maria Jazinta their daughters and Juan Varela their son in law filed a criminal complaint against Joseph de Thore, Juez ordinario (local judge) of Cee. The suit alleges that on 4 January 1718 the judge ordered "without reason or motive" that Maria de Lema y Andrade and her three daughters be handcuffed and locked in jail. That order was carried out by a group of over ten men. When the son in law Juan Varela intervened, he was also arrested and jailed, and the oxen and cart which they had with them were confiscated. The initial pleading is followed by over 25 pages of written testimony taken from several parties and witnesses. From that testimony the story emerges. On the morning of 4 January 1718, the de Lema group went out to a garden plot "which is said to be in the jurisdiction of Sardiñeiro." In a lawsuit previously filed by Francisco Lopez Soneira, he had claimed the plot belonged to him as property inherited from his parents Juan Lopez Soneira and Elvira Gonzalez and before them it was held by Antonio Gonzalez de Lamas " $y$ otros sus mayores ${ }^{36}$." The counterclaim by Francisca de Santillana was that they were possessors of the garden plot as heirs of her father, Antonio Perez de Pazos who for ten, twenty or more years had farmed it. He had been absent about a year and his whereabouts unknown, and since then Marina de Santillana his wife had used it until her death about six months ago. Since that time Francisca, her daughters and siblings had used it to grow coles. Apparently on the morning of the arrest the de Lema group had gone out and started to tear out the cabbage in order to sow rye. A disagreement arose with the Santillana group and a verbal fight ensued. The local authorities were called in and arrested the de Lema group. No indication appears as to the final outcome. On two occasions, nearly a dozen pages into the written testimony, the de Lema group at the garden plot is described by opposing witnesses from villages near the property

\footnotetext{
${ }^{35}$ ARCHIVO DEL REINO DE GALICIA, Pleitos Civiles, Legajo 17944, number 25, 27 Jan. 1718. Lawsuit brought by Francisco Lopez Soneira against Francisca Santillana and others. Archivo del Reino de Galicia, Pleitos Civiles, Legajo 9324, number 57, 17 Feb. 1675. Lawsuit brought by Francisco Lopez Soneira (RIN 67) and Maria de Dios his wife and Ciprian Gonzlaez and his wife Ana Maira de Lema against various persons. A second lawsuit dealt with the division of the inheritances from Sebastian de Dios and his wife Maria de Lema, great grandparents of Ana Maria de Lema, but contained little new genealogical data.

${ }^{36}$ And others her elders. As used here these words appear to refer to earlier ancestors or relatives 
as "Maria de Lema y Andrade and D Maria Josepha, D Euxenia and D Maria Jazinta her daughters and Juan_de Mourelle her son in law."

We had expected this document would only provide family history color. Nevertheless, upon a careful reading, Juan Varela, who is clearly identified as the son in law of Francisco Lopez Soneira and Maria de Lema y Andrade, is mentioned twice as Juan de Mourelle in this single document, substantiating our previous assumption that this is one individual using both surnames interchangeably.

\section{Conclusions}

Considerable indirect and circumstantial evidence verifies that the Juan Varela who appears as the father of Benita del Lema is the same as Juan de Mourelle who married Ana Maria de Lema in 1717. All of the known facts fit together to support the hypothesis that this is but one man, and no contradictory evidence appears.

1) Parish records in Cee establish for Juan de Mourelle Varela and Ana Maria de Lema a family of five children beginning with their marriage in 1717, including the birth of Benita de Lema in 1721. There are no contradictions, nor viable alternative possibilities. The only major missing pieces in the family picture are the baptism and marriage of Theresa, but her filial relationship to Juan Varela is clearly established by direct evidence in several documents.

2) Juan de Mourelle's mother was a Varela and in like manner all of the various surnames used by Juan and Ana Maria, as well as by a number of her ancestors, are accounted for among their ancestors, except Figueroa, which will require further research on the Mourelle line.

3) The appearances of Domingo Mourelle and Juan de Mourelle in the protocolos of Cee corroborate the fact that Juan is Juan de Varela and offer no contradiction, except possible alternative places of residence for Domingo and Juan.

4) None of the documents offering direct evidence concerning Juan, Ana Maria and their children contradict the conclusion that Juan Varela and Juan de Mourelle are the same person.

Going beyond the system of women taking their mothers' surnames used throughout most of the eighteenth century and until about 1825, this study of the family of Benita de Lema clearly illustrates the flexibility of surname usage in Galicia in the period before 1790. Figure 3 shows the varied surnames used by Benita de Lema and her husband and parents. 


\begin{tabular}{|l|l|l|l|}
\hline $\begin{array}{l}\text { Benita } \\
(1721-1800)\end{array}$ & $\begin{array}{l}\text { Ambrosio } \\
(1715-1789)\end{array}$ & $\begin{array}{l}\text { Juan } \\
(1690 \text { ?-1745) }\end{array}$ & $\begin{array}{l}\text { Ana Maria } \\
(1690-1753)\end{array}$ \\
\hline de Lema & do Campo & Varela Figueroa & $\begin{array}{l}\text { Freire de Andrade } \\
\text { de Lema }\end{array}$ \\
\hline Varela de Lema & Blanco & de Lema & de Lema \\
\hline $\begin{array}{l}\text { Varela Freire de } \\
\text { Andrade }\end{array}$ & Blanco do Campo & de Mourelle & $\begin{array}{l}\text { de Lema de } \\
\text { Andrade }\end{array}$ \\
\hline & Blanco de Lema & Varela de Lema & $\begin{array}{l}\text { de Lema y } \\
\text { Andrade }\end{array}$ \\
\hline
\end{tabular}

Figure 3

Surnames used by Benita de Lema, her husband and parents

With the exception of Figueroa (for which insufficient research has been done), each of the surnames used appeared earlier in the person's pedigree, or in the case of Juan's and Ambrosio's use of the de Lema surname, that of a wife. Clearly in Galicia men and women during the time before 1790 could select surnames from their fathers or mothers, from their extended pedigree, or even from their spouse's family, and often did so.

\section{BIBLIOGRAPHY}

R.G. Dun \& Co. Credit Report Volumes, vol. 345, Baker Library Historical Collections, New York, Harvard Business School University.

Ryskamp, George R., "La transmisión de apellidos en España y las Colonias Americanas (1500-1900)", in Eduardo Pardo Guevara (ed.), España y América, un escenario común, Santiago de Compostela, Consejo Superior de Investigaciones Científicas; Xunta de Galicia, 2005, pages 341-364.

Ryskamp, George R., The Female Surname System in Galicia and Extremadura in the XVII Century, Riverside (California), Hispanic Family History Research, 1987 